\title{
Profil Konten HOTS dan LOTS dalam Buku Teks Siswa Kelas V Kurikulum 2013
}

\author{
Nurani Hadnistia Darmawan ${ }^{1 *}$, Hilman Hilmawan ${ }^{2}$, Hilma Hulwiyah ${ }^{3}$ \\ 1STKIP Bina Mutiara, Sukabumi, Indonesia \\ 2STKIP Bina Mutiara, Sukabumi, Indonesia \\ 3STKIP Bina Mutiara, Sukabumi, Indonesia \\ *Corresponding author: nhalfaruq@gmail.com
}

\begin{abstract}
This study aimed to determine the composition of HOTS and LOTS content as well as to explain the cognitive dimensions used in the textbooks of class $V$ students on the theme of healthy food in the 2013 curriculum. This research was a descriptive qualitative research with content analysis techniques on the fifth grade student's textbook on the theme of healthy food. The data analysis techniques used were data reduction, data display, conclusion drawing, and verification. The results showed that there was HOTS content with a percentage of $80 \%$ while LOTS content got a percentage of $20 \%$. The percentage of HOTS content in the aspect of analyzing skills (C4) was $27 \%$, evaluating (C5) was $40 \%$, and creating (C6) was 33\%. The LOTS load on the aspect of remembering skills (C1) was $21 \%$, understanding (C2) was $62 \%$, and applying (C3) was $17 \%$. The results of this study provide information about the sections in the textbook content that still contain LOTS content, so that in that section, teachers can design learning, enrich teaching materials, and create HOTS-oriented evaluation content.
\end{abstract}

Keywords: curriculum 2013; HOTS; LOTS; textbook

\section{ABSTRAK}

Penelitian ini bertujuan untuk mengetahui komposisi konten HOTS dan LOTS serta menjelaskan dimensi kognitif yang digunakan dalam buku teks siswa kelas V tema makanan sehat kurikulum 2013. Penelitian ini merupakan penelitian kualitatif deskriptif dengan teknik analisis konten terhadap buku teks siswa kelas $\mathrm{V}$ tema makanan sehat. Teknik analisis data yang dilakukan yakni reduksi data, display data, penarikan kesimpulan, dan verifikasi. Hasil penelitian menunjukkan bahwa terdapat konten HOTS dengan persentase $80 \%$ sedangkan konten LOTS mendapatkan persentase $20 \%$. Adapun persentase muatan HOTS pada aspek keterampilan menganalisis (C4) sebesar 27\%, mengevaluasi (C5) sebesar 40\%, dan mencipta (C6) sebesar 33\%. Adapun muatan LOTS pada aspek keterampilan mengingat (C1) sebesar 21\%, memahami (C2) sebesar 62\%, dan mengaplikasikan (C3) sebesar $17 \%$. Hasil penelitian ini memberikan informasi tentang bagian-bagian pada konten buku teks yang masih terdapat muatan LOTS, sehingga pada bagian tersebut, guru dapat mendesain pembelajaran, memperkaya materi ajar, serta membuat konten evaluasi yang berorientasi pada HOTS. Kata Kunci: buku teks; HOTS; kurikulum 2013; LOTS

\section{Pendahuluan}

Buku teks berperan penting dalam proses pembelajaran. Adanya buku teks dapat mempermudah peserta didik pada pelaksanaan proses belajar. Keberadaan buku teks tersebut diharapkan dapat membantu terciptanya pelaksanaan proses pembelajaran yang kondusif, sehingga peserta didik mampu menggapai tujuan pembelajaran yang sudah direncanakan. Selain hal tersebut, buku teks juga memiliki pengaruh yang baik untuk menaikkan capaian belajar peserta didik. Oleh sebab itu, buku teks tersebut didesain agar dapat memudahkan peserta didik turut berperan aktif dalam setiap proses belajar. Menurut Widodo et al., (2019) ada sebuah transformasi pandangan pembelajaran pada Kurikulum 2013, dimana peserta 
didik menjadi pusat di dalam pembelajaran (student centered). Pembelajaran tersebut bertujuan supaya peserta didik dapat lebih cakap dalam membentuk wawasan.

Adapun pendekatan proses belajar yang digunakan di kurikulum 2013 yaitu pendekatan pembelajaran saintifik yakni termuat dalam 5M diantaranya mengamati, menanya, mencoba, mengasosiasikan dan mengkomunikasikan. Pendekatan proses belajar tersebut diharapkan dapat menjadikan pembelajaran lebih partisipatif, kolaboratif serta mampu menumbuhkan peserta didik agar mampu berpikir tingkat tinggi. Pernyataan itu sejalan dengan pendapat Elyana et al., (2017) yakni pada Kurikulum 2013 proses belajar ditekankan kepada dimensi pedagogik modern serta melatih peserta didik agar dapat berpikir secara terstruktur, dengan mengaplikasikan keterampilan berpikir tingkat tinggi pada proses belajar.

Anderson dan Krathwohl dalam (Nabilah et al., 2020) menyatakan bahwa sesuai dengan teori Bloom tahapan berpikir terdiri dari dua macam yaitu Lower-Order Thinking Skills (LOTS) terdiri dari keterampilan mengingat (C1), memahami (C2), mengaplikasikan (C3), serta Higher-Order Thinking Skills (HOTS) yang terdiri dari keterampilan menganalisis (C4), mengevaluasi (C5) dan mencipta (C6). Peserta didik akan mampu berada pada tahapan berpikir HOTS apabila peserta didik mampu terlebih dahulu menguasai LOTS. Fajriyah \& Agustini (2018) mengemukakan bahwa HOTS pada tingkat pendidikan dasar menjadi sesuatu hal yang diutamakan dalam mencetak peserta didik yang kompeten selaras dengan standar kompetensi lulusan SD/MI. Sehingga proses belajar ditekankan untuk melatih HOTS peserta didik. HOTS yaitu keterampilan menganalisis suatu informasi serta pemecahan sebuah masalah dengan berpikir secara mendalam, menghasilkan berbagai ide atau pemikiran, dan mampu menyelesaikan permasalahan sampai ke akarnya (Barrat dalam Fanani \& Kusmaharti, 2018). HOTS merupakan tahapan berpikir yang lebih tinggi, dimana peserta didik tidak hanya mampu memahami teori, tetapi juga dapat mengaplikasikan pengetahuan tersebut di dalam kehidupannya.

Pada Kurikulum 2013, penentuan isi dan evaluasi di dalam buku teks idealnya berorientasi pada kemampuan HOTS sesuai dengan mngacu pada standar internasional. Sebagaimana hasil kajian Programme for International Student Assessment (PISA) mengungkapkan yakni kemampuan peserta didik di Indonesia dalam menelaah suatu keterangan dan masalah begitu rendah (Subadar, 2017). Berdasarkan hal tersebut, maka isi pelajaran harus berientasi HOTS yang berbasis pemecahan masalah di dalam pembelajaran. Adapun konten evaluasi yang disusun agar peserta didik tidak hanya belajar untuk mengerjakan berbagai pertanyaan yang berada pada level kognitif rendah, tetapi juga peserta didik dilatih untuk menjawab soal-soal yang berada pada level kognitif tinggi. Oleh sebab itu, buku teks mempunyai peran yang fundamental dalam meningkatkan keterampilan berpikir tingkat tinggi bagi peserta didik. Karena buku teks merupakan bahan ajar yang berkaitan langsung dengan peserta didik dalam kegiatan belajar.

Pembelajaran berbasis HOTS harus dibiasakan dalam aktivitas pembelajaran di sekolah. Hal tersebut supaya peserta didik mampu terbiasa dalam memecahkan masalah yang sulit dalam kehidupannya. Maharani \& Utami (2019) menjabarkan bahwasannya dengan proses belajar yang bermuatan berpikir tingkat tinggi akan mampu membentuk pola pikir peserta didik menjadi lebih kreatif, berpikir secara mendalam, dan mampu menyelesaikan suatu permasalahan. Anindtya \& Suwarjo dalam (Fajriyah \& Agustini, 2018) memaparkan yakni sesuai dengan tinjauan instansi Partnership for 21st Century Skill, keterampilan berpikir kritis 
merupakan bagian dari HOTS yakni keterampilan yang sangat dibutuhkan bagi peserta didik di tengah perkembangan zaman supaya peserta didik mampu menyeleksi suatu informasi dengan baik dan benar. Pernyataan itu sejalan dengan pemaparan Morocco dalam (Abidin, 2015) yakni untuk menyikapi segala tantangan pada abad 21 ini diperlukan beberapa keterampilan yang wajib dikuasai seperti keterampilan pemahaman yang tinggi, keterampilan berpikir kritis, keterampilan berpikir kreatif serta keterampilan dalam berkomunikasi dan berkolaborasi. Empat keterampilan di atas merupakan bagian dari HOTS yang wajib terdapat pada buku teks serta harus diterapkan pada kegiatan belajar.

Sesuai dengan penjabaran tersebut dapat disimpulkan buku teks harus bermuatan pengembangan keterampilan berpikir tingkat tinggi yang berada pada tingkatan berpikir C4, C5, dan C6. Apabila peserta didik terbiasa berpikir tingkat tinggi maka peserta didik akan mempunyai karakter yang kuat. Sejalan dengan yang dikatakan oleh Sobri et al., (2019) bahwa karakter yang kuat bisa ditumbuhkan dengan budaya sekolah, seperti diadakannya pembiasaan pembelajaran berbasis masalah. Oleh karena itu peserta didik akan mampu terbiasa dalam menyelesaikan suatu permasalahan.

Berdasarkan kajian relevan yang dilakukan oleh Pratiwi dan Alimuddin (2019) mengenai analisis kebutuhan bahan ajar bermuatan HOTS di SD pada buku teks kelas VI tema persatuan dalam perbedaan, memaparkan bahwa buku teks tersebut belum seluruhnya memenuhi bahan ajar yang berorientasi pada higher-order thinking skills (HOTS). Selain itu, Kusainun (2019) yang mengkaji tentang relevansi HOTS dengan materi pokok Matematika pada tema 1 kelas 1SD menjelaskan bahwa pada umumnya indikator matematika yang terdapat pada tema tersebut masih termasuk dalam kategori berpikir tingkat rendah atau LOTS.

Berlandaskan pemaparan di atas, penelitian ini bertujuan untuk memastikan bahwa konten HOTS termuat pada keseluruhan isi buku teks siswa. Oleh karena itu, kajian dan telaah buku teks siswa ini, tidak hanya memfokuskan pada kemunculan HOTS dalam bahan ajarnya saja atau relevansi dengan indikator pembelajaran, seperti penelitian-penelitian yang telah dilakukan sebelumnya. Penelitian ini juga berfokus untuk mengkaji dan menelaah tentang keseluruhan muatan HOTS dan LOTS serta dimensi kognitif yang digunakan, sehingga pengkajian dan penelaahan dilakukan pada setiap halaman dalam buku teks siswa termasuk di dalamnya menelaah konten evaluasi pembelajaran.

\section{Metode Penelitian}

Metode dalam penelitian ini adalah pendekatan kualitatif dengan menggunakan teknik kajian isi/analisis konten. Teknik analisis konten merupakan sebuah teknik yang memungkinkan peneliti untuk mempelajari hal-hal yang dilakukan manusia secara implisit dengan menganalisis komunikasi termasuk salah satunya melalui tulisan/buku teks (Fraenkel, Wallen, \& Hyun, 2012). Alasan penggunaan metode penelitian ini karena tujuannya untuk mendeskripsikan muatan HOTS dan LOTS yang terdapat pada buku teks siswa kelas V tema makanan sehat. Teknik analisis data menggunakan model Miles Huberman yang terdiri dari pengumpulan data, display data, penarikan kesimpulan, serta verifikasi (Sugiyono, 2015). Adapun pemeriksaan keabsahan data dilakukan dengan uji dependabilitas, uji tersebut dilaksanakan dengan teknik pemeriksaan seluruh prosedur penelitian (Sugiyono, 2015). 


\section{Hasil dan Pembahasan}

Penelitian ini menghasilkan persentase perbedaan konten HOTS dengan LOTS pada setiap subtema dan persentase ragam aspek keterampilan berpikir pada konten HOTS dan LOTS pada setiap subtema.

\section{Perbedaan Konten yang Bermuatan HOTS dengan LOTS}

Berikut ini merupakan grafik perbedaan konten HOTS dan LOTS pada setiap subtema:

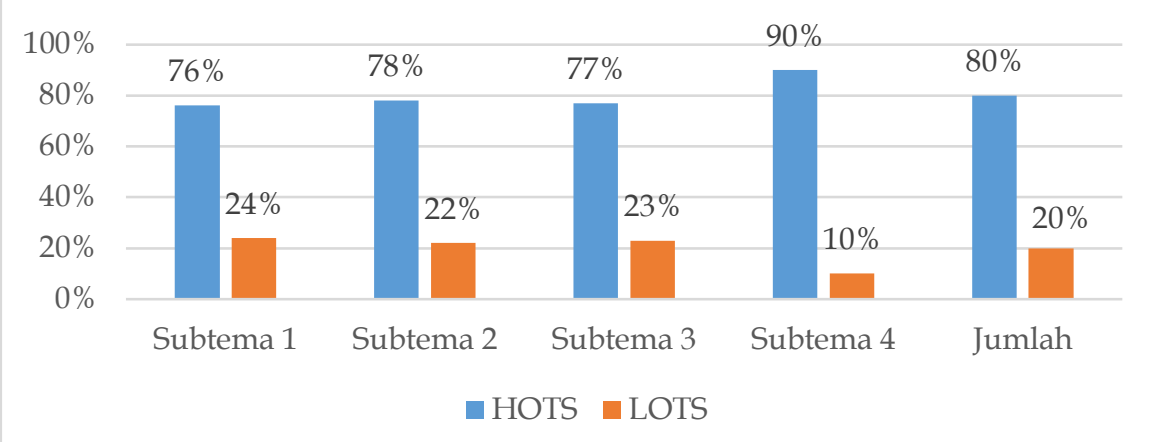

Gambar 1. Grafik Perbedaan Konten HOTS dan LOTS Pada Setiap Subtema

Hasil penelitian menunjukkan bahwa konten HOTS memiliki persentase $80 \%$ atau 224 muatan, sedangkan konten LOTS mendapatkan persentase $20 \%$ atau 63 muatan. Data tersebut menjelaskan bahwasannya konten HOTS pada buku teks siswa kelas V tema makanan sehat lebih besar dari pada konten LOTS. Hal tersebut mengungkapkan bahwa buku teks tersebut telah menekankan kepada pengembangan HOTS untuk menstimulasi peserta didik.

Berdasarkan grafik pada gambar 1 didapati subtema 4 memiliki persentase konten bermuatan HOTS paling banyak dibandingkan dengan subtema lainnya yakni $90 \%$. Hal tersebut dapat dimengerti karena subtema 4 terdiri dari pembelajaran literasi serta proyek yang secara khusus diciptakan untuk memfasilitasi peserta didik dalam berpikir tingkat tinggi. Menurut Ahmad et al., dalam (Kwangmuang et al., 2021) HOTS merupakan elemen yang penting dalam pendidikan karena manfaatnya dalam meningkatkan kemampuan belajar peserta didik, mengurangi kelemahan peserta didik, bermanfaat dalam menafsirkan, mensintesis, memecahkan masalah, dan mengendalikan informasi, gagasan, dan kegiatan sehari-hari. Selain itu, menurut Heong (2012) bahwa pemikiran kreatif hanya dapat diciptakan melalui berpikir tingkat tinggi, bukan berpikir tingkat rendah melalui pengaplikasian pengetahuan yang dipelajari dalam kehidupan sehari-hari.

Pada buku teks siswa kelas V tema 3 "Makanan Sehat" subtema 4, terdapat kegiatan proyek yang terbagi ke dalam enam kegiatan diantaranya yakni proyek satu berjudul "Travel Agent", proyek dua berjudul "Toko Mainan", proyek tiga berjudul "Kisah Padi dari Sawah ke Meja Makan", proyek empat berjudul "Batik dalam Pecahan", proyek lima berjudul "Penyuluh Kesehatan", dan proyek enam berjudul "Bertanyalah kepada Ahlinya". Setiap proyek meminta peserta didik untuk dapat melaksanakan berbagai kegiatan sehingga peserta didik mampu menggapai tujuan yang telah direncanakan. Kegiatan-kegiatan tersebut menstimulasi peserta didik untuk dapat berpikir tingkat tinggi. Pada subtema 4 peserta didik difasilitasi agar mampu menganalisis suatu materi, menilai atau mengambil suatu keputusan, dan menciptakan atau membuat konsep, ide, atau produk baru. 
Kemampuan menganalisis dan menilai termasuk ke dalam critical thinking yang berarti bagian dari HOTS. Hal itu senada dengan yang diungkapkan Sani (2019) bahwa agar mampu membuat suatu keputusan, peserta didik harus mampu untuk menalar, menimbang, menelaah dan mengevaluasi. Menurut Victor-Chmil dalam (Jarvis \& Baloyi, 2020) bahwa berpikir kritis adalah proses kognitif yang digunakan untuk menganalisis pengetahuan. Selain itu, kemampuan membuat konsep, ide, atau produk baru termasuk ke dalam kemampuan berpikir kreatif yang berarti bagian dari HOTS. Hal tersebut sejalan dengan pendapat Sani (2019) bahwa seseorang yang berpikir kreatif akan mampu menghasilkan konsep, ide, atau produk baru hasil dari pengembangan berfikir dari berbagai sudut pandang. Kemampuan berpikir kritis dan berpikir kreatif sangat diperlukan oleh seseorang untuk memecahkan suatu permasalahan yang kompleks.

Sesuai grafik pada gambar 1 didapati subtema 4 memiliki konten LOTS yang paling sedikit dibandingkan dengan subtema-subtema yang lainnya yaitu sebesar $10 \%$. Hal tersebut dapat dipahami karena pada subtema 4 terdiri dari kegiatan proyek dan literasi untuk mengembangkan keterampilan berpikir tingkat tinggi peserta didik. Sehingga muatan LOTS yang terdapat pada subtema 4 paling sedikit dibandingkan dengan subtema-subtema yang lain. Adapun contoh konten bermuatan LOTS yang terdapat pada subtema 4 diantaranya yaitu peserta didik diminta untuk melaksanakan penyuluhan kesehatan kepada teman-teman yang mengunjungi kelompoknya berdasarkan prosedur yang telah ditetapkan dan peserta didik diminta untuk berperan sebagai seorang ahli yang menyampaikan informasi mengenai topik tertentu kepada temannya. Kedua contoh tersebut merupakan konten yang bermuatan LOTS yang berada pada level kognitif C3 (mengaplikasikan), menurut Ruwaida (2019) mengaplikasikan adalah kemampuan melaksanakan atau menerapkan prosedur pada keadaan tertentu.

\section{Perbedaan Aspek Keterampilan Berpikir dalam Konten HOTS Pada Setiap Subtema}

Higher order thinking skills (HOTS) terdiri atas tiga tingkatan keterampilan berpikir yakni keterampilan berpikir menganalisis (C4), mengevaluasi (C5), serta mencipta (C6). Berikut ini akan disajikan grafik perbedaan aspek keterampilan berpikir dalam konten HOTS pada setiap subtema:

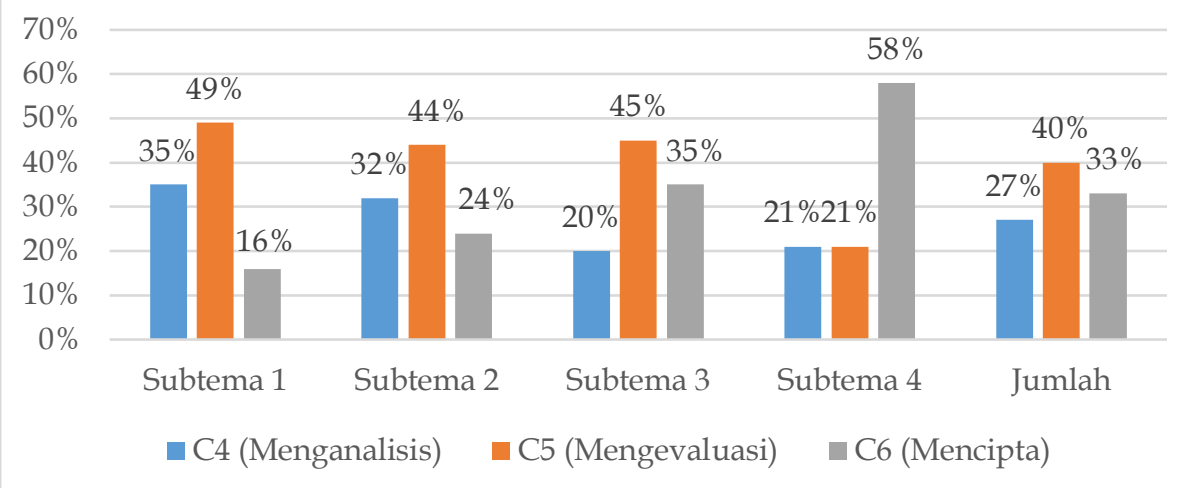

Gambar 2. Grafik Perbedaan Aspek Keterampilan Berpikir dalam Konten HOTS Pada Setiap Subtema 
Keterangan:

a. Level kognitif menganalisis (C4), contoh konten yang memperlihatkan muatan pada tingkatan berpikir ini yaitu: mengidentifikasi suatu permasalahan yang dipaparkan dalam jenis soal, menelaah gambar, menelaah bacaan, merincikan suatu materi, menemukan suatu informasi, menghubungkan suatu materi dengan materi lainnya, mengidentifikasi suatu materi, dan membedakan suatu permasalahan yang disajikan dalam bentuk pertanyaan.

b. Level kognitif mengevaluasi (C5), contoh konten yang memperlihatkan muatan pada tingkatan berpikir ini yaitu: menarik kesimpulan suatu bacaan, membandingkan hasil diskusi, membuat suatu keputusan, memvalidasi sebuah materi, menimbang jawaban terbaik, memberikan komentar terhadap hasil karya antar kelompok, merefleksi materi yang telah dipelajari, menilai informasi dalam teks, dan memberikan pendapat berupa masukan atau saran mengenai suatu permasalahan.

c. Level kognitif mencipta (C6), contoh konten yang memperlihatkan muatan pada tingkatan berpikir ini yaitu: membuat reka cipta gambar, mempresentasikan hasil karya atau hasil diskusi di depan kelas, membuat alur diagram, membuat poster sistem pencernaan manusia, membuat komik sederhana, mengkreasikan alat musik ritmis sederhana, membuat kartu informasi, membuat sebuah iklan, merancang sebuah poster gangguan pencernaan, membuat laporan observasi, membuat poster iklan layanan masyarakat, membuat sebuah buku kecil, membuat berita koran, dan mendekorasi cetakan tangan.

Secara keseluruhan muatan HOTS yang berada pada level kognitif menganalisis (C4) sebesar $27 \%$ atau 65 muatan, level kognitif mengevaluasi (C5) sebesar $40 \%$ atau 99 muatan, dan level kognitif mencipta (C6) sebesar $33 \%$ atau 60 muatan. Terdapat perbedaan persentase level kognitif HOTS pada masing-masing subtema. Muatan HOTS yang paling banyak tersedia pada buku teks kelas $\mathrm{V}$ tema makanan sehat yaitu berada pada level kognitif mengevaluasi (C5).

Adapun grafik pada gambar 2 didapati bahwa level kognitif HOTS yang paling banyak muncul dalam buku teks siswa kelas $\mathrm{V}$ tema 3 makanan sehat yaitu berada pada level kognitif C5 (Mengevaluasi) sebesar 40\%. Hal tersebut karena pada buku teks siswa kelas V tema 3 makanan sehat konten HOTS yang paling banyak muncul yaitu konten yang meminta peserta didik untuk dapat memberikan judgment terhadap suatu hal. Contohnya seperti terdapat dalam lembar halaman 26 buku teks kelas $\mathrm{V}$ tema 3 makanan sehat, dimana peserta didik diminta untuk memberikan pendapatnya mengenai alasan singkong dapat digunakan sebagai pengganti nasi.

Menurut Musrikah (2018) bahwa C5 (mengevaluasi) adalah kemampuan dalam menentukan tingkatan sesuatu sesuai dengan kriteria atau aturan tertentu. Kemampuan tersebut diantaranya yaitu kemampuan melaksanakan evaluasi, kemampuan dalam memberikan penilaian terhadap suatu hal, kemampuan menyanggah, kemampuan dalam memilih dan memutuskan, serta kemampuan untuk memberikan dukungan (Taubah, 2019).

Selain itu, sesuai grafik pada gambar 2 didapati level kognitif HOTS yang paling sedikit muncul dalam buku teks siswa kelas $\mathrm{V}$ tema 3 makanan sehat yaitu berada pada level kognitif C4 (Menganalisis) sebesar 27\%. Contohnya terdapat dalam lembar halaman 23 buku teks siswa 
kelas $\mathrm{V}$ tema 3 makanan sehat, dimana peserta didik diminta untuk mengidentifikasi jenis interaksi yang terjadi di lingkungan sekitar. Menurut Taubah (2019) menganalisis merupakan kemampuan dalam menspesifikasi elemen atau aspek-aspek, baik itu dalam materi pelajaran atau dalam proses pembelajaran. Kemampuan menganalisis yang perlu dimiliki oleh peserta didik diantaranya kemampuan dalam membandingkan dan memeriksa. Adapun menurut Musrikah (2018) menganalisis yakni kemampuan dalam memisahkan konsep ke dalam berbagai komponen serta menghubungkannya diantara satu sama lain supaya mendapatkan pemahaman yang baik.

Berdasarkan grafik pada gambar 2 didapati pada subtema 4 level kognitif HOTS yang paling banyak muncul yaitu berada pada level kognitif C6 (Mencipta) yaitu sebesar 58\%. Hal tersebut dapat dipahami karena pada subtema 4 terdiri dari kegiatan-kegiatan proyek yang meminta peserta didik untuk dapat menghasilkan produk-produk maupun ide-ide yang baru. Adapun contoh konten HOTS yang berada pada level kognitif C6 (Mencipta) yang terdapat pada subtema 4 diantaranya yaitu peserta didik diminta untuk membuat iklan media cetak, mempresentasikan suatu karya, membuat gambar hewan, membuat kartu informasi, membuat sebuah karangan narasi, membuat kreasi gambar motif batik, dan membuat naskah iklan elektronik.

Menurut Musrikah (2018) mencipta adalah kemampuan dalam memadukan berbagai komponen menjadi sesuatu yang baru atau orisinil. Adapun menurut Taubah (2019) diharapkan peserta didik dapat memiliki kemampuan dalam mengkreasi ide atau gagasan sendiri, seperti kemampuan mendesain, kemampuan mengembangkan keilmuan, kemampuan menulis, kemampuan memformulasikan konsep-konsep baru, serta kemampuan mengkonstruksi.

Konten HOTS yang berada pada level kognitif C4 (Menganalisis) dan C5 (mengevaluasi) pada subtema 4 memiliki jumlah muatan yang sama yaitu sebesar $21 \%$. Contoh konten HOTS yang berada pada level kognitif C4 (Menganalisis) yang terdapat pada subtema 4 diantaranya yaitu peserta didik diminta untuk mengidentifikasi keunggulan dari sebuah produk, mengidentifikasi proses petani ketika menanam padi, mengidentifikasi salah satu organ pencernaan mengenai definisi, gejala, serta pencegahannya, dan merincikan hal apa saja yang belum dipahami peserta didik mengenai sebuah topik tertentu. Adapun contoh konten HOTS yang berada pada level kognitif C5 (Mengevaluasi) yang terdapat pada subtema 4 diantaranya yaitu peserta didik diminta untuk memberikan komentar dan saran kepada kelompok yang telah selesai tampil, melakukan refleksi setelah selesai pembelajaran, memilih salah satu topik pembelajaran yang dikuasai, dan memutuskan jawaban berdasarkan pertanyaan yang diajukan mengenai topik tertentu.

\section{Perbedaan Aspek Keterampilan Berpikir dalam Konten LOTS Pada Setiap Subtema}

Lower order thinking skills (LOTS) terdiri atas tiga tingkatan keterampilan berpikir yakni keterampilan berpikir mengingat (C1), memahami (C2), dan mengaplikasikan (C3). Berikut ini akan disajikan grafik perbedaan aspek keterampilan berpikir dalam konten LOTS pada setiap subtema: 


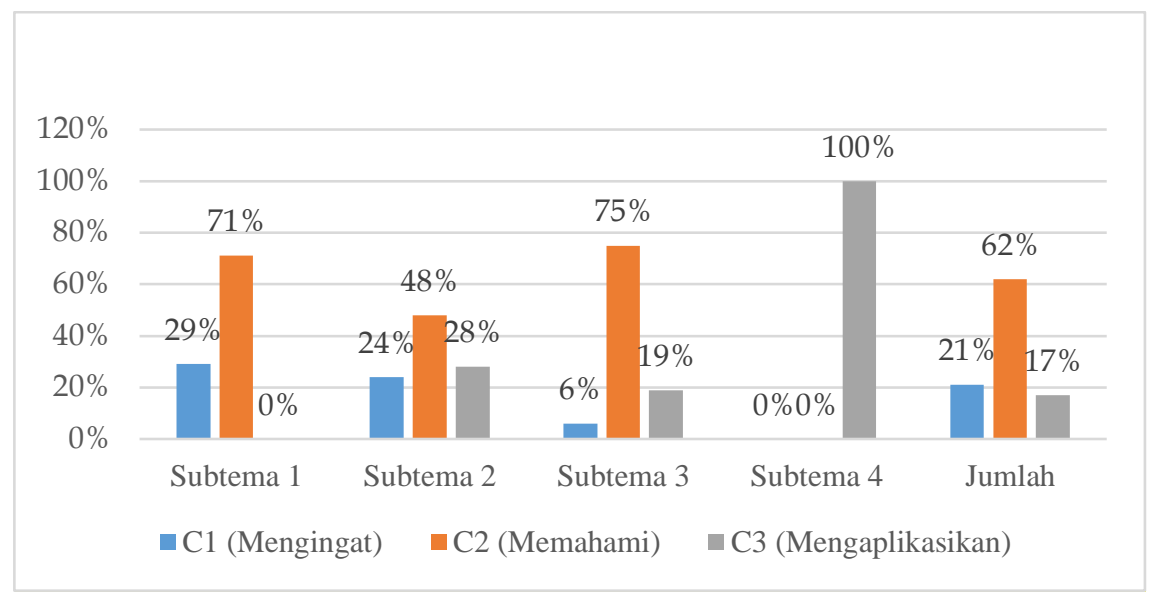

Gambar 3. Grafik Perbedaan Aspek Keterampilan Berpikir dalam Konten LOTS Pada Setiap Subtema

Keterangan:

a. Level kognitif mengingat (C1), contoh konten yang memperlihatkan muatan pada tingkatan berpikir ini yaitu: menyebutkan contoh-contoh makanan yang sehat, menuliskan hal-hal apa saja yang telah dilakukan bersama teman-teman di sepanjang hari, dan mengulas kembali alasan seseorang bisa terkena maag.

b. Level kognitif memahami (C2), contoh konten yang memperlihatkan muatan pada tingkatan berpikir ini yaitu: menguraikan kriteria makanan yang sehat, menerangkan definisi dari kata kunci, menjabarkan karakteristik sebuah kata kunci, mendiskusikan iklan, mengemukakan fungsi umum sistem pencernaan manusia, mendeskripsikan adat istiadat yang dimiliki keluarga, dan menjelaskan interaksi sosial dan alam yang terdapat di lahan pertanian padi.

c. Level kognitif mengaplikasikan (C3), contoh konten yang memperlihatkan muatan pada tingkatan berpikir ini yaitu: menerapkan prosedur pembuatan cairan oralit, menerapkan prosedur pembuatan minuman kesehatan, memeragakan dialog percakapan, memeragakan naskah iklan elektronik, memeragakan tarian kancet papatai, melakukan survei lapangan, dan melaksanakan penyuluhan kesehatan.

Secara keseluruhan muatan LOTS yang berada pada level kognitif mengingat (C1) sebesar $21 \%$ atau 13 muatan, level kognitif memahami (C2) sebesar $62 \%$ atau 39 muatan, dan level kognitif mengaplikasikan (C3) sebesar $17 \%$ atau 11 muatan. Terdapat perbedaan persentase level kognitif LOTS pada masing-masing subtema. Muatan LOTS yang paling banyak tersedia pada buku teks kelas $\mathrm{V}$ tema makanan sehat yaitu berada pada level kognitif memahami (C2).

Sesuai grafik pada gambar 3 didapati level kognitif LOTS terbanyak terdapat dalam buku teks siswa kelas $\mathrm{V}$ tema 3 makanan sehat yaitu berada pada level kognitif $\mathrm{C} 2$ (memahami) sebesar 62\%. Hal tersebut karena pada buku teks siswa kelas V tema 3 makanan sehat konten LOTS yang paling banyak muncul yaitu konten yang meminta peserta didik untuk dapat merumuskan makna dari pesan pembelajaran. Contohnya seperti terdapat dalam lembar halaman 23 buku teks siswa kelas V tema 3 makanan sehat, dimana peserta didik diminta untuk menjelaskan interaksi sosial dan interaksi dengan lingkungan alam yang tertera pada lahan pertanian padi. Menurut Taubah (2019) bahwa memahami merupakan kemampuan dalam menjelaskan ide atau konsep. Adapun menurut Musrikah (2018) 
memahami adalah kemampuan dalam memahami intruksi serta memperjelas konsep yang sudah dipelajari baik dalam bentuk diagram, tulisan, atau lisan.

Sesuai grafik pada gambar 3, terlihat bahwa level kognitif LOTS yang paling sedikit muncul dalam buku teks siswa kelas $\mathrm{V}$ tema 3 makanan sehat yaitu berada pada level kognitif C3 (mengaplikasikan) sebesar 17\%. Contohnya seperti yang terdapat dalam lembar halaman 78 buku teks siswa kelas $\mathrm{V}$ tema 3 makanan sehat, dimana peserta didik diminta untuk memeragakan gerakan tarian kancet papatai. Menurut Taubah (2019) bahwa mengaplikasikan yaitu menerapkan informasi pada ranah yang berbeda. Adapun kata kerja mengaplikasikan diantaranya yaitu mengoperasikan, menggunakan, mengilustrasikan, dan mendemonstrasikan. Adapun menurut Musrikah (2018) mengaplikasikan merupakan kemampuan dalam melaksanakan suatu hal atau menerapkan konsep dalam keadaan tertentu.

Selain itu dapat diketahui bahwa pada subtema 1 terdapat perbedaan persentase level kognitif LOTS yang cukup mencolok diantaranya yaitu C1 (mengingat) sebesar 29\%, C2 (memahami) sebesar 71\%, dan C3 (mengaplikasikan) sebesar 0\%. Hal tersebut menunjukkan bahwa pada subtema 1 sama sekali tidak ditemukan konten LOTS yang berada pada level kognitif C3 (mengaplikasikan), hal tersebut menunjukkan bahwa konten yang bemuatan LOTS pada subtema 1 ini tidak tersebar secara merata. Pernyataan tersebut sejalan dengan pendapat Widodo et al., (2019) bahwa apabila perbedaan persentase level kognitif yang terdapat pada konten HOTS atau LOTS tidak terlalu mencolok, maka hal itu menunjukkan bahwa level kognitif yang terdapat dalam konten HOTS atau LOTS tersebut tersebar secara merata.

Adapun contoh konten LOTS pada subtema 1 yang berada pada level kognitif C1 (Mengingat) diantaranya yaitu terdapat pada lembar halaman 2 buku teks siswa kelas $\mathrm{V}$ tema 3 makanan sehat, dimana peserta didik diminta untuk dapat menyebutkan contoh-contoh makanan yang sehat. Sedangkan contoh konten LOTS pada subtema 1 yang berada pada level kognitif C2 (Memahami) diantaranya yaitu terdapat pada lembar halaman 13 buku teks kelas $\mathrm{V}$ tema 3 makanan sehat, dimana peserta didik diminta untuk menerangkan isi dari sebuah iklan.

Sesuai grafik pada gambar 3 didapati semua tingkatan level kognitif LOTS termuat dalam subtema 3. Pada subtema 3 terdapat perbedaan persentase level kognitif LOTS yang cukup mencolok diantaranya yaitu C1 (Mengingat) sebesar 6\%, C2 (Memahami) sebesar 75\%, dan C3 (Mengaplikasikan) sebesar 19\%. Hal tersebut menunjukkan bahwa konten yang bemuatan LOTS pada subtema 3 ini tidak tersebar secara merata.

Pada subtema 3 konten LOTS yang paling banyak muncul yaitu berada pada level kognitif C2 (memahami), dimana peserta didik diminta untuk mampu merumuskan makna dari pesan pembelajaran. Contohnya seperti terdapat dalam lembar halaman 85 buku teks kelas $\mathrm{V}$ tema 3 makanan sehat, dimana peserta didik diminta untuk menjabarkan isi dari sebuah iklan yang terdapat pada lembar halaman tersebut. Adapun contoh konten yang bermuatan C1 (Mengingat) pada subtema 3 yaitu terdapat dalam lembar halaman 115 buku teks kelas $\mathrm{V}$ tema 3 makanan sehat, dimana peserta didik diminta untuk menyebutkan caracara dalam pembuatan batik dan jenis-jenis motif batik nusantara. Terakhir, yaitu contoh konten yang bermuatan C3 (Mengaplikasikan) pada subtema 3 yaitu terdapat dalam lembar halaman 107 buku teks siswa kelas V tema 3 makanan sehat, dimana peserta didik diminta 
untuk melaksanakan survei lapangan mengenai gangguan sistem pencernaan berdasarkan prosedur tertentu.

Sesuai grafik pada gambar 3 didapati pada subtema 4 level kognitif LOTS yang muncul hanya berada pada level kognitif C3 (mengaplikasikan) sebesar 100\%, contohnya seperti terdapat dalam lembar halaman 122 buku teks kelas $\mathrm{V}$ tema 3 makanan sehat, dimana peserta didik diminta untuk dapat melaksanakan penyuluhan kesehatan kepada teman-teman yang mengunjungi kelompoknya. Pada subtema 4 sama sekali tidak terdapat konten yang berada pada level kognitif C1 (mengingat) dan C2 (memahami), hal tersebut menunjukkan bahwa konten yang bemuatan LOTS pada subtema 1 ini tidak tersebar secara merata.

Adapun kemampuan berpikir tingkat rendah yang termuat dalam buku teks siswa kelas $\mathrm{V}$ tema 3 makanan sehat ini diantaranya yaitu kemampuan menyebutkan, mengulas kembali, menguraikan, menerangkan, mendeskripsikan, menjabarkan, mendiskusikan, mengemukakan, menjelaskan, menerapkan prosedur, memeragakan, dan melaksanakan suatu prosedur.

Konten yang bermuatan HOTS pada buku teks siswa kelas V tema "Makanan Sehat" lebih tinggi daripada konten yang bermuatan LOTS. Hal tersebut sejalan dengan pendapat Desmita (2012) bahwa peserta didik pada rentan umur 11-12 tahun sudah mampu membuat suatu pertimbangan dan sudah mampu berpikir abstrak. Hal itu dinamakan dengan fase operasional formal. Pada tahap ini, peserta didik mampu berpikir secara tepat dan dinamis , serta dapat menghadapi berbagai persoalan yang kompleks. Pada fase operasional formal, peserta didik mampu menumbuhkan dugaan awal terbaik, serta berpikir secara runtut dalam memecahkan permasalahan (Santrock dalam Bujuri, 2018). Proses berpikir tersebut merupakan bagian dari HOTS. Pola pembelajaran hipotesis-deduktif dapat dipergunakan untuk menumbuhkan critical thinking bagi peserta didik (Adnyana dalam Bujuri, 2018).

Menurut Bujuri (2018) pada umur 11 tahun (kelas 5 SD), kemampuan berpikir peserta didik sudah masuk ke dalam tingkatan kognitif C5 dan C6. Adapun pada umur 12 tahun (kelas 6 SD) masuk pada tingkatan berpikir C5 dan C6 yang lebih baik. Menurutnya, tingkatan kognitif ini masuk dalam fase operasional formal, dimana peserta didik sudah mampu membuat pertimbangan-pertimbangan serta menentukan pilihan yang terbaik terhadap suatu kondisi dengan dasar ilmiah. Peserta didik sudah mampu menciptakan inovasi berdasarkan pengetahuan-pengetahuan sebelumnya.

Berdasarkan penjelasan di atas, sangatlah sesuai apabila pada buku teks kelas $\mathrm{V}$ tema "Makanan Sehat" konten pembelajaran yang ditekankan yaitu konten pembelajaran yang berorientasi pada HOTS yang berada pada level kognitif menganalisis (C4), mengevaluasi (C5), dan mencipta (C6).

Pembelajaran HOTS yang terdapat dalam buku teks siswa kelas V tema "Makanan Sehat" tersebut telah dipadukan bersama pembelajaran multiliterasi, sehingga peserta didik difasilitasi agar mampu menguasai berbagai keterampilan yang disediakan. Adapun contoh kegiatan literasi pada buku teks kelas $\mathrm{V}$ tema makanan sehat yaitu literasi seni pada kegiatan ayo bernyayi "mars hidup sehat" dan ayo mencoba "tangga nada mayor atau minor, literasi budaya dalam kegiatan ayo membaca "pesona tana toraja, tarian daerah, sisingaan, tari kancet papatai, bogor siap gelar cap go meh, sanggar tari wadah para penari tradisional" dan ayo mengamati "aneka tradisi baju adat", dan literasi sosial dalam kegiatan ayo mengamati "mengamati aktivitas pasar" dan ayo membaca "perkumpulan petani pemakai air". Menurut 
Abidin (2015) dengan pembelajaran multiliterasi peserta didik dapat memaparkan suatu informasi dengan tepat.

Penguraian konten HOTS dan LOTS dalam buku teks siswa kelas V tema "Makanan Sehat" ini sudah memenuhi karakteristik bahan ajar yang baik. Menurut Akbar (2013) terdapat beberapa ketentuan mengenai buku teks yang baik, contohnya yaitu berpusat pada peserta didik yakni buku teks yang mampu menumbuhkan rasa ingin tahu peserta didik, memiliki sifat konstruktivis, memungkinkan bagi peserta didik untuk dapat mengimplementasikan makna yang tertera pada suatu teks atau bacaan.

Rasa ingin tahu peserta didik pada buku teks siswa kelas V tema "Makanan Sehat" telah disediakan dengan adanya segala macam kegiatan pembelajaran. Dalam menumbuhkan rasa ingin tahu peserta didik ditumbuhkan kemampuan berpikir dengan cara konstruktivistik yang berarti peserta didik menemukan sendiri pengetahuan tersebut melalui berbagai kegiatan seperti ayo mengamati, ayo membaca, ayo mencoba, ayo berdiskusi, ayo berlatih, ayo renungkan, dan ayo berkreasi. Dengan kegiatan yang bersifat konstruktivistik diharapkan peserta didik dapat mengembangkan kemampuannya dalam berpikir kritis.

Halpern dalam (Sani, 2019) berpendapat bahwa proses berpikir kritis dibutuhkan dalam membuat sebuah keputusan dan dalam menyelesaikan suatu permasalahan (problem solving). Lebih lanjut Norris dalam (Sani, 2019) menyatakan bahwa seorang pemikir kritis akan berusaha menemukan alasan pemikiran, pengetahuan yang cukup, menggunakan sumber yang dapat dipercaya dan mengungkapkan sumber tersebut, mencari jalan lain, menimbang pendapat orang lain serta diri sendiri dengan seksama, menahan pertimbangan apabila bukti dan alasan tidak cukup kuat, dan mencari informasi yang akurat sebanyak mungkin.

Adapun kemampuan berinteraksi peserta didik dalam buku teks kelas $\mathrm{V}$ tema "Makanan Sehat" telah disediakan dengan adanya berbagai aktivitas seperti ayo berdiskusi serta aktivitas dengan orang tua. Dengan adanya aktivitas-aktivitas tersebut keterampilan berkomunikasi dan berkolaborasi peserta didik telah difasilitasi dengan baik, mengingat keterampilan-keterampilan tersebut sangat dibutuhkan dalam menghadapi abad 21.

Terdapat beberapa keterampilan abad 21 yang terdapat pada buku teks kelas $\mathrm{V}$ tema "Makanan Sehat" diantaranya yaitu kompetensi pemahaman yang tinggi, contohnya pada halaman 5 terdapat aktivitas ayo berdiskusi dimana peserta didik diminta untuk memahami tiga buah iklan dengan menganalisis kata kunci dan membuat sebuah kesimpulan berdasarkan hasil diskusi kelompok mengenai kata kunci tersebut. Kompetensi berpikir kritis contohnya termuat pada halaman 65-66 dalam kegiatan ayo mengamati, dimana peserta didik diminta untuk menghubungkan gambar-gambar aneka tradisi dan baju adat dengan gambar peta Indonesia. Kompetensi kolaborasi dan komunikasi contohnya termuat pada halaman 82 dalam kegiatan bersama orang tua, dimana peserta didik diminta untuk melakukan kerja sama dengan orang tua dalam membuat simpulan mengenai hal-hal besar yang sudah peserta didik pelajari dalam satu minggu terakhir. Kompetensi berpikir kreatif contohnya termuat pada halaman 111 dalam kegiatan ayo berkreasi, dimana peserta didik diminta untuk membuat sebuah rancangan kreasi motif batik Nusantara. Beberapa keterampilan di atas menunjukkan pembelajaran berorientasi HOTS yang sudah tersedia pada buku teks kelas V tema "Makanan Sehat" tersebut dalam berbagai kegiatan pembelajaran.

Namun pada buku teks tersebut tidak ditemukan konten yang menyajikan aspek inovasi yang bisa menumbuhkan peserta didik untuk menciptakan sesuatu terbaru utamanya 
berhubungan dengan teknologi serta pengetahuan yang akan datang. Menurut Wheelihan dalam (Heong et al., 2012) bahwa bahwa kreativitas dan inovasi merupakan kunci penting keberhasilan dalam segala bidang di era perkembangan yang pesat ini.

Sesuai dengan pemaparan di atas kesimpulan bahwasannya buku teks siswa kelas $\mathrm{V}$ tema 3 "Makanan Sehat" telah menyediakan pembelajaran yang berlandaskan HOTS seperti keterampilan menelaah, memerinci, membandingkan, menyimpulkan, menemukan, memberikan penilaian, menghubungkan, mengidentifikasi, merefleksi, merancang, menimbang, memvalidasi, memutuskan, mempresentasikan, memilih, membedakan, membuat, dan mengkreasi.

\section{Kesimpulan}

Berlandaskan hasil penelitian pada buku teks siswa kelas V Tema 3 Makanan Sehat, tedapat muatan HOTS dengan persentase $80 \%$ serta masih terdapat muatan LOTS dengan persentase $20 \%$. Pada buku teks siswa tersebut juga tidak ditemukan konten yang dapat merangsang peserta didik untuk menciptakan sesuatu terbaru utamanya berhubungan dengan teknologi serta pengetahuan yang akan datang. Selain itu, hasil penelitian ini memberikan informasi tentang bagian-bagian pada konten buku teks yang masih terdapat muatan LOTS, sehingga pada bagian tersebut, guru dapat mendesain pembelajaran, memperkaya materi ajar, serta membuat konten evaluasi yang berorientasi pada HOTS. Adapun hal yang dapat dilakukan untuk penelitian selanjutnya adalah melakukan pengembangan bahan ajar berbagai mata pelajaran di sekolah dasar berorientasi HOTS untuk memperkaya sumber belajar siswa.

\section{Daftar Pustaka}

Abidin, Y. (2015). Pembelajaran multiliterasi: Sebuah jawaban atas tantangan pendidikan abad ke-21 dalam konteks keIndonesiaan. Bandung: PT Refika Aditama.

Akbar, S. (2013). Instrumen Perangkat Pembelajaran. Bandung: Usaha Rosdakarya.

Bujuri, D. A. (2018). Analisis Perkembangan Kognitif Anak Usia Dasar dan Implikasinya dalam Kegiatan Belajar Mengajar. Literasi. IX (1). Tersedia di laman: https://ejournal.almaata.ac.id/index.php/LITERASI/article/download/720/993

Desmita. (2012). Psikologi Perkembangan Peserta Didik. Bandung: PT Remaja Rosdakarya.

Elyana, Yennita, \& Fakhruddin. (2017). Analisis Higher-Order Thinking Skills (HOTS) siswa MAN 2 Model Pekanbaru dalam menyelesaikan soal ujian nasional Fisika tingkat SMA/MA. Jurnal Online Mahasiswa (JOM) Bidang Keguruan Dan Ilmu Pendidikan, 4(1), 1-9. https://jom.unri.ac.id/index.php/JOMFKIP/article/view/13522

Fajriyah, K. \& Agustini, F. (2018). Analisis Keterampilan Berpikir Tingkat Tinggi Siswa Kelas V SD Pilot Project Kurikulum 2013 di Kota Semarang. Elementary School, 5(1), 1-6. Tersedia di laman: https://journal.upy.ac.id/index.php/es/article/view/594/0

Fanani, A., \& Kusmaharti, D. (2018). Pengembangan Pembelajaran Berbasis HOTS (HigherOrder Thinking Skill) di Sekolah Dasar Kelas V. Jurnal Pendidikan Dasar, 9(1), 1-11. Tersedia di laman: https://journal.unj.ac.id/index.php/jpd/article/view/JPD.91.01

Fraenkel, J. R., Wallen, N. E., \& Hyun, H. H. (2012). How to design and evaluate research in education (8th ed.). New York: Mc Graw HIll. 
Heong, Y. M., Yunos, J. M., Othman, W., Hassan, R., Kiong, T. T., \& Mohamad, M. M. (2012). The Needs Analysis of Learning Higher Order Thinking Skills for Generating Ideas. Procedia - Social and Behavioral Sciences, 59, 197-203. https:// doi.org/10.1016/j.sbspro.2012.09.265

Jarvis, M. A., \& Baloyi, O. B. (2020). Scaffolding in reflective journaling: A means to develop higher order thinking skills in undergraduate learners. International Journal of Africa Nursing Sciences, 12(October 2019), 100195. https:/ / doi.org/10.1016/j.ijans.2020.100195

Kusainun, N. (2019). Relevansı Materı Pokok Matematıka pada Tema 1 Kelas I SD dengan HOTS (Higher-Order Thinkıng Skılls). Jurnal JPSD, 6(1). Tersedia di laman: https://journal.uad.ac.id/index.php/JPSD/article/download/14145/pdf

Kwangmuang, P., Jarutkamolpong, S., Sangboonraung, W., \& Daungtod, S. (2021). The development of learning innovation to enhance higher order thinking skills for students in Thailand junior high schools. Heliyon, 7(6), e07309. https://doi.org/10.1016/j.heliyon.2021.e07309

Maharani, A. D., \& Utami, T. S. (2019). HOTS pada Assesment Pembelajaran Tematik Muatan Pembelajaran IPA Siswa Sekolah Dasar. Prosiding Seminar Nasional Pendidikan Dasar, 502 510. http://eproceedings.umpwr.ac.id/index.php/semnaspgsd/article/view/1059

Musrikah, M. (2018). Higher Order Thingking Skill (Hots) Untuk Anak Sekolah Dasar Dalam Pembelajaran Matematika. Martabat: Jurnal Perempuan dan Anak, 2(2). https:/ / doi.org/10.21274/martabat.2018.2.2.339-360

Nabilah, M., Sitompul, S. S., \& Hamdani, H. (2020). Analisis Kemampuan Kognitif Peserta Didik Dalam Menyelesaikan Soal Momentum Dan Impuls. Jurnal Inovasi Penelitian Dan Pembelajaran Fisika, 1(1), 1. https://doi.org/10.26418/jippf.v1i1.41876

Pratiwi, W., \& Alimuddin, J. (2019). Analisis Kebutuhan Bahan Ajar Bermuatan Keterampilan Berpikir Tingkat Tinggi di Sekolah Dasar. Elementary School, 6 (1), 27-32. Tersedia di laman: https://journal.upy.ac.id /index.php/es/article/view/95

Ruwaida, H. (2019). Proses Kognitif dalam Taksonomi Bloom Revisi: Analisis Kemampuan Mencipta (C6) pada Pembelajaran Fikih di MI Miftahul Anwar Desa Banua Lawas. Jurnal Ilmiah Pendidikan Madrasah Ibtidaiyah, 4(1), 51-76. https://jurnal.stiqamuntai.ac.id/index.php/al-madrasah/article/download/168/115

Sani, R. A. (2019). Pembelajaran Berbasis HOTS (Higher Order Thinking Skills). Tangerang: Tsmart Printing.

Sobri, M., Nursaptini, Widodo, A., \& Sutisna, D. (2019). Pembentukan karakter disiplin siswa melalui kultur sekolah. Jurnal Pendidikan IPS, 6(1), 61-71. http://journal.uny.ac.id/index.php/hsjpi

Subadar. (2017). Penguatan Pendidikan Karakter (PPK) Berbasis Higher-Order Thinking Skills (HOTS). Jurnal Pedagogik, 04(01), 81-93. https://ejournal.unuja.ac.id/index.php/pedagogik/article/download/9/9.

Sugiyono. (2015). Metode Penelitian Pendidikan (Pendekatan Kuantitatif, Kualitatif dan $R$ \& D). Bandung: CV Alfabeta.

Taubah, M. (2019). Penilaian HOTS dan Penerapannya di SD/MI. Elementary: Islamic Teacher Journal, 7(2), 197. https:/ / doi.org/10.21043/elementary.v7i2.6368

Widodo, A., Indraswati, D., Radiusman, Umar, \& Nursaptini. (2019). Analisis Konten HOTS dalam Buku Siswa Kelas V Tema 6 " Panas dan Perpindahannya" Kurikulum 2013. In 
Jurnal Pendidikan dan Pembelajaran Dasar (Vol. 12, Issue 1). Tersedia di laman: http://ejournal.uin-malang.ac.id/index.php/madrasah/article/view/7744 